\title{
On the effects of human galanin in man
}

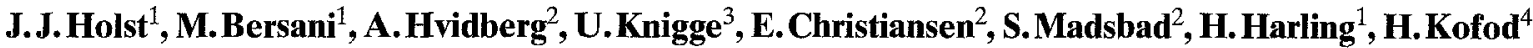 \\ ${ }^{1}$ Department of Medical Physiology, the Panum Institute, University of Copenhagen, Copenhagen, Denmark \\ ${ }^{2}$ Department of Endocrinology, Hvidovre Hospital, University of Copenhagen, Copenhagen, Denmark \\ ${ }^{3}$ Department of Surgical Gastroenterology, Hvidovre Hospital, University of Copenhagen, Copenhagen, Denmark \\ ${ }^{4}$ Novo Nordisk, Bagsværd, Denmark
}

\begin{abstract}
Summary. Human galanin was recently isolated and sequenced and was found to differ from porcine galanin, hitherto used for studies in humans, in several important respects. We therefore synthesized and purified human galanin and infused it i.v. at a rate of $74 \mathrm{pmol} \cdot \mathrm{kg}^{-1}$. $\min ^{-1}$ into six healthy volunteers for 60 min during a hyperglycaemic clamp. The clamp was achieved by i. v. infusion of glucose at a rate which in a control experiment had been demonstrated to maintain the plasma glucose level at 12 $13 \mathrm{mmol} / \mathrm{l}$ for $90 \mathrm{~min}$. Galanin concentrations reached a plateau of approximately $1500 \mathrm{pmol} / 1$ throughout the infusion as opposed to pre-infusion and control levels of 20 $30 \mathrm{pmol} / \mathrm{l}$. The glucose levels obtained in the two experiments were indistinguishable. Plasma levels of C-peptide and insulin increased significantly in both experiments and
\end{abstract}

the dynamic concentration curves were almost identical. Glucagon concentrations in plasma decreased significantly and similarly. Growth hormone levels, however, increased eight-fold during galanin infusions. Galanin was eliminated from plasma with a half-life of $3.7 \pm 0.4 \mathrm{~min}$, similar to that of porcine galanin. It is concluded that human galanin powerfully stimulates growth hormone secretion in man, but has no effect on pancreatic endocrine secretion or glucose metabolism in the concentrations obtained in this study.

Key words: Insulin secretion, glucagon secretion, growth hormone secretion, C-peptide secretion, neuropeptides, hyperglycaemic clamp.
Galanin was originally isolated from porcine small intestine [1] and was found to be a peptide of 29 amino acids with a carboxyterminal amidation. Galanin, which is a relatively abundant neuropeptide in both the central and the peripheral nervous system [2], may be found in nerve fibres in the pancreas $[3,4]$ and has been found to inhibit insulin secretion in rodents and dogs [5]. Furthermore, galanin receptors have been identified on cell lines derived from rat insulinomas, and mechanisms for its inhibitory effects have been studied [6-8]. However, porcine galanin infused into humans in high doses had no effect on glucose-stimulated insulin secretion [9], and, surprisingly, stimulated both basal and glucose-stimulated insulin secretion in isolated perfused porcine pancreas [10]. In contrast, porcine galanin has been shown to be a potent stimulator of growth hormone secretion in both experimental animals and in humans $[2,9]$. We recently isolated human galanin from normal tissues and were the first to determine its amino acid sequence [11]. The structure turned out to differ considerably from that of porcine galanin in that the peptide consisted of 30 amino acids, was without $\alpha$-carboxy-amidation, and had 4 amino acid substitutions.
We therefore decided to synthesize the peptide and study its effects on insulin secretion and glucose metabolism in humans, using for this purpose a hyperglycaemic clamp. For comparison, we also measured plasma growth hormone levels.

\section{Subjects and methods}

\section{Galanin}

Human galanin 1-30 was synthesized on an Applied Biosystems 430 A peptide synthesizer, using the standard BOC-chemistry protocol, utilizing t-butoxycarbonyl as protection for the amino acid $\alpha$-amino group, dicyclohexylcarbodiimide as condensing agent and trifluoroacetic acid to deprotect the protected peptide $\alpha$-amino group during synthesis. The raw product was isolated after cleavage from the resin following the standard low/high hydrofluoric acid procedure [12]. Resin-bound amino acids and protected amino acids were purchased from Applied Biosystems (Warrington, UK). The free peptide was purified as previously described in detail [11]. First Sephadex $G 50$ superfine grade gel filtration in acetic acid was used followed by HPLC using LKB equipment and $300-5 \mu \mathrm{m}$ C-18 Nucleosil cartridges. The peptides were eluted using linear gradients of ace- 

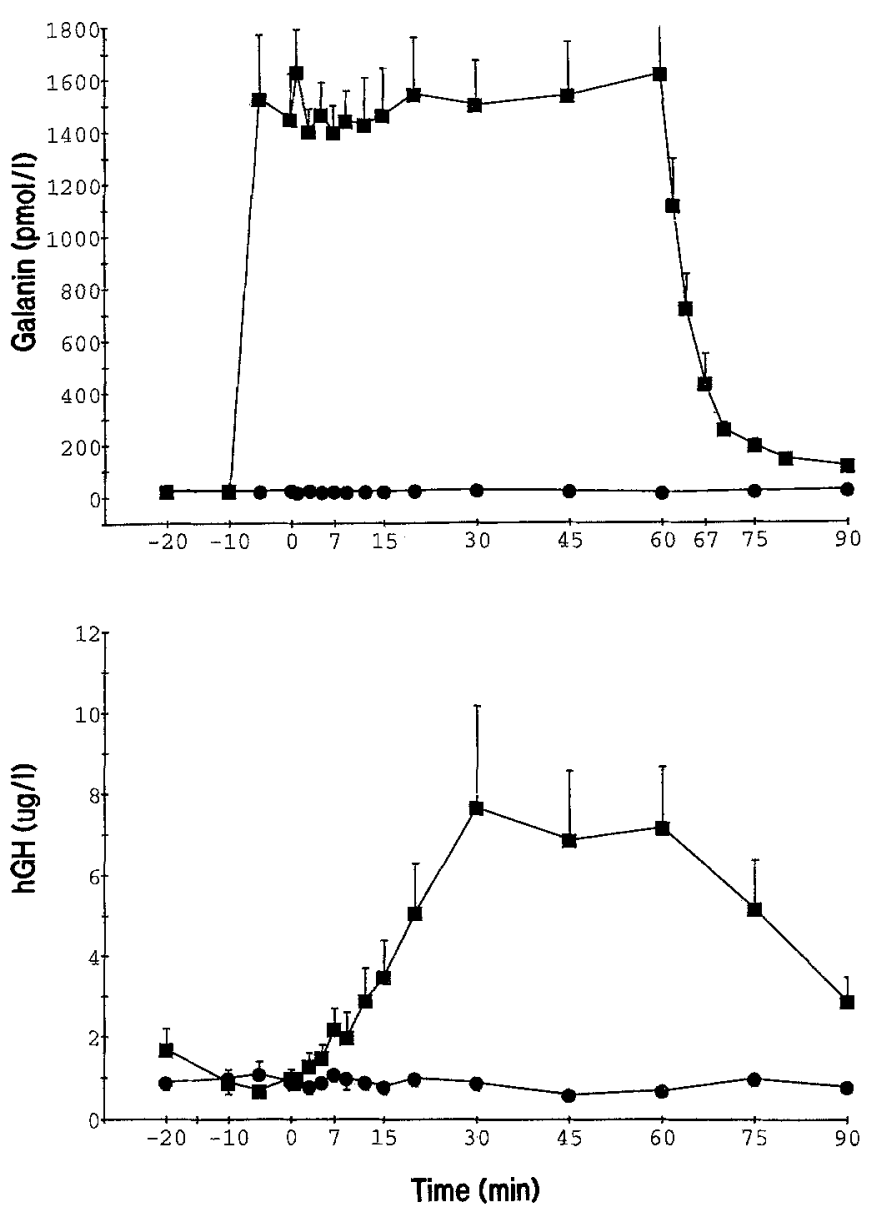

Fig. 1. Plasma concentrations of galanin (upper panel) and growth hormone ( $\mathrm{hGH}$, lower panel) during administration of human galanin ( $39 \pm 3 \mathrm{nmol}$ as an i.v. bolus at $-10 \mathrm{~min}$ and continued as an i.v. infusion of $74 \pm 6 \mathrm{pmol} \cdot \mathrm{kg}^{-1} \cdot \mathrm{min}^{-1}$ from -10 to $60 \mathrm{~min}$ ) in six normal men. An i.v. hyperglycaemic clamp was performed from 0 to $90 \mathrm{~min}$. Mean \pm SEM

tonitrile in $0.15 \%$ heptafluorobutyric acid in water. A gradient of 30 to $36 \%$ acetonitrile over $30 \mathrm{~min}$ was used for the final run. The eluted fractions were analysed for optical density at $226 \mathrm{~mm}$ and galanin immunoreactivity using a radioimmunoassay against the $\mathrm{N}$ terminal part of porcine galanin described previously and demonstrated to react with human galanin [11]. The correctness of the structure of the purified, synthetic human galanin was verified by amino acid and sequence analysis as described [11]. The purified peptide was dried and reconstituted in $0.15 \mathrm{~mol} / \mathrm{h}$ sodium chloride with $0.5 \%$ human serum albumin (Albumin Nordisk; Novo Nordisk, Bagsværd, Denmark, guaranteed to be free of hepatitis-B surface antigen and human immunodeficiency virus (HIV) antibodies) and subjected to sterile filtration. Appropriate amounts of peptide for each experimental subject were dispensed into glass ampules and stored frozen under sterile conditions until the day of the experiment. Samples of the infusion solution were analysed for galanin content using a radioimmunoassay for human galanin (see below).

\section{Subjects}

Six healthy male volunteers (age range $25-46$ years, mean weight $75 \pm 2 \mathrm{~kg}$ ) were recruited from the hospital and laboratory staff. None were taking any medication. Informed consent was obtained after the purpose, nature and possible risks of the study had been carefully explained. The study was approved by the local ethical committee.
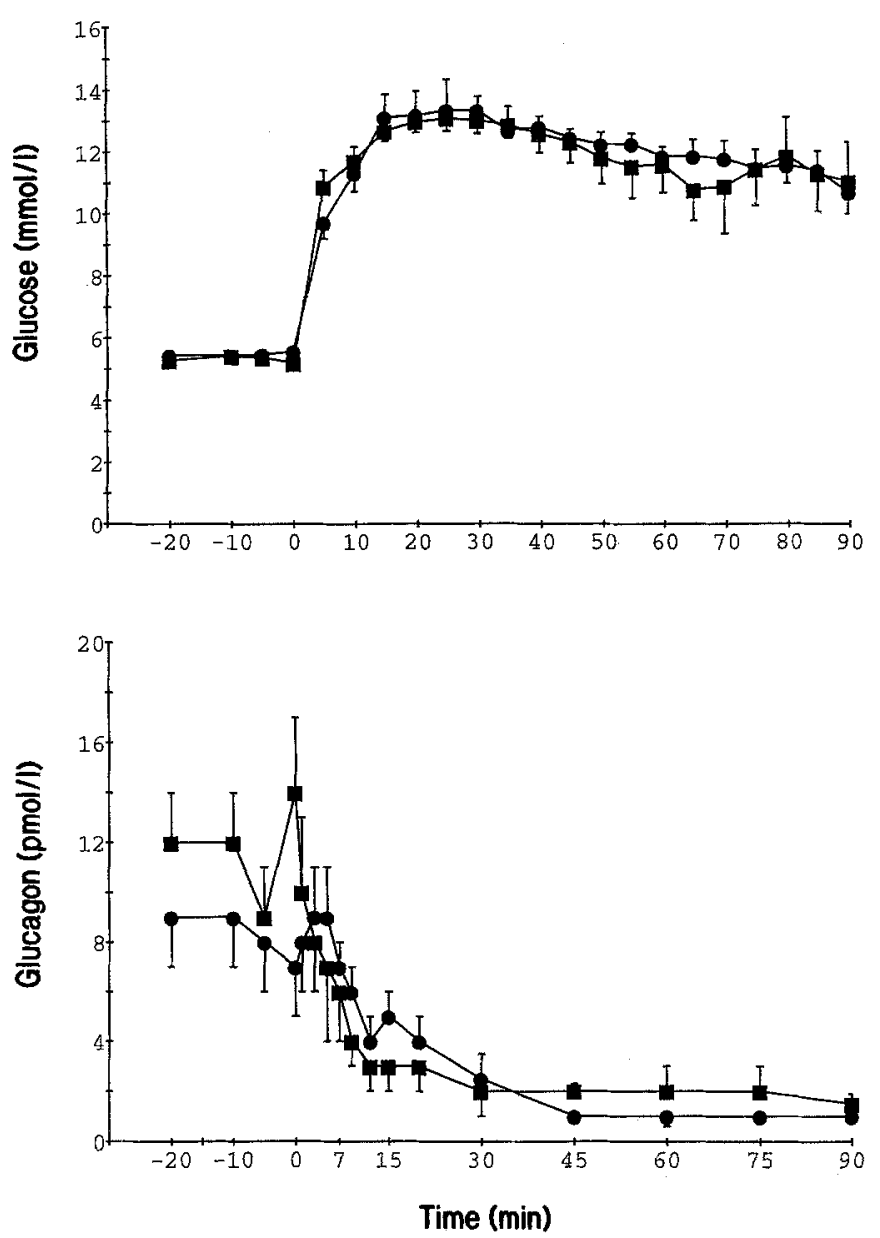

Fig. 2. Plasma concentrations of glucose (upper panel) and glucagon (lower panel) during i.v. infusion of human galanin in six normal men. See legend to Figure 1 for details

\section{Infusion protocol}

The subjects were studied on two separate occasions at least 2 weeks apart. On the first day vehicle was infused, on the second day, galanin. All infusions were performed with the subjects recumbent with indwelling cannulas inserted into forearm or cubital veins of both arms: one for infusion of galanin or vehicle, one for infusion of glucose and one for blood sampling. The contents of the galanin ampules were diluted further with $\mathrm{NaCl}$ and $0.5 \%$ human albumin as above and infused using a high-precision infusion pump (Perfusor; Secura, Braun Melsungen, FRG). The peptide was administered as an $i$. v. bolus injection (over $60 \mathrm{~s}$ ) of $39 \pm 3 \mathrm{nmol}$ in a volume of $4 \mathrm{ml}$ at $-10 \mathrm{~min}$ (Fig. 1) and continued as an i. v. infusion of $74 \pm 6 \mathrm{pmol} \cdot \mathrm{kg}^{-1} \cdot \mathrm{min}^{-1}$ from -10 to $60 \mathrm{~min}$ at a flow rate of $34 \mathrm{ml} / \mathrm{h}$. At time 0 min on both experimental days a priming dose of $50 \%$ glucose was injected over $5 \mathrm{~min}$ at an average rate of $3.2 \mathrm{ml} / \mathrm{m}^{2}$ surface area of the subjects studied. Thereafter, glucose clamping was achieved by infusion of a $20 \%$ glucose solution from 0 to $90 \mathrm{~min}$ using a high precision infusion pump (Infusemat, Secura). Blood for glucose determination was sampled every $5 \mathrm{~min}$ and analysed on a Yellow Spring Glucose Analyzer (model 23 A, Yellow Springs Instruments, Yellow Springs, Ohio, USA), and the infusion rate adjusted to yield a plateau of $10-12 \mathrm{mmol} / 1$ in the control experiment. The same infusion rate was used in the galanin experiment. Blood for hormone analysis was sampled as indicated in Figures 2 and 3. Additional blood samples for determination of the elimination rate of galanin after termination of the infusion were obtained as indi- 

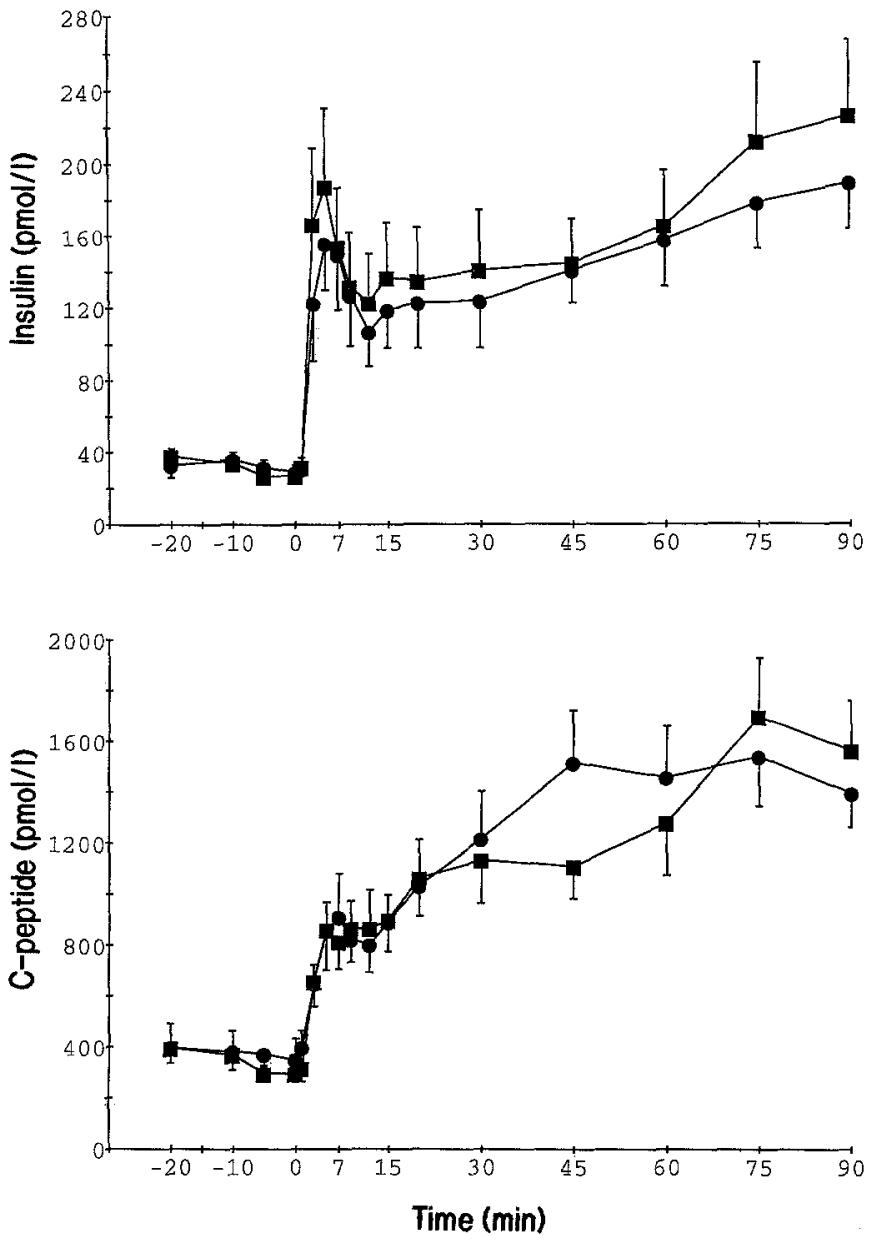

Fig. 3. Plasma levels of insulin (upper panel) and C-peptide (lower panel) during i.v. infusion of human galanin in six normal men. See legend to Figure 1 for details

cated in Figure 1. Plasma was collected in chilled tubes containing $6 \mathrm{mmol} / \mathrm{l} \mathrm{EDTA} \mathrm{(Merck,} \mathrm{Darmstadt,} \mathrm{FRG)} \mathrm{and} \mathrm{aprotinin,} \mathrm{500,000}$ kallikrein inhibitory units/litre (Trasylol, Bayer AG, Leverkusen, FRG) and kept on ice until centrifugation at $4^{\circ} \mathrm{C}$. Plasma was stored at $-20^{\circ} \mathrm{C}$ until analysis.

\section{Measurements}

Pulse rate and blood pressure were measured with regular intervals during galanin infusion. Plasma growth hormone and insulin and glucagon concentrations were measured using previously described methods [13-15]. Plasma C-peptide levels were measured as described by Heding [16] using a commercially available radioimmunoassay kit based on antiserum K6 (a generous gift from the Immunochemical Department, Novo Nordisk, Bagsværd, Denmark). Sensitivity was below $0.06 \mathrm{nmol} / \mathrm{l}$ and intra-assay coefficient of variation in the normal concentration range below $5 \%$. Galanin levels in plasma were measured using a new antiserum (code nr. 91042), raised in a rabbit against human galanin as above, coupled to bovine serum albumin with carbodiimide using procedures previously described [10, 17]. Human galanin was also used as standard and for ${ }^{125} \mathrm{I}$-labelling using previously described methods $[10,17]$. The assay sensitivity was better than $5 \mathrm{pmol} / 1$ and the intra-assay coefficient of variation was $6 \%$. Plasma samples were extracted with ethanol (final concentration $70 \%$ volume/volume) before radioimmunoassay. Extracted from a $6 \%$ solution of albumin in assay buffer the recovery of galanin was $70 \%$. When corrected for this loss the recovery of galanin added to plasma deviated less than $15 \%$ from expected values.

\section{Calculations}

Calculations of the galanin pharmacokinetics were based on the principles of Goldstein et al. [18]. The metabolic clearence rate (MCR) was calculated as: $M C R=R_{i n} / C_{p l(s s)}$, where $R_{i n}$ is the galanin infusion rate, calculated as the measured galanin concentration in the infusate multiplied by the infusion rate of $0.57 \mathrm{ml} / \mathrm{min} . \mathrm{C}_{\mathrm{pl}(\mathrm{ss})}$ is the individual incremental plateau concentration of galanin (mean of the concentrations in the period -5 to 60 min minus the mean preinfusion level). The elimination rate constant $(\mathrm{k})$ was determined as the slope of the concentration curve from 60 to $70 \mathrm{~min}$, in which plasma galanin values were clearly elevated above basal levels. The halftime of disappearance $\left(\mathrm{t}_{1 / 2}\right)$ was calculated as $\ln 2 / \mathrm{k}$. The apparent space of distribution $\left(V_{d}\right)$ was calculated as $M C R / k$.

\section{Statistical analysis}

Analysis of variance was used to evaluate changes as a function of time and the Wilcoxon test for evaluation of differences between control and galanin infusion experiments.

\section{Results}

All subjects experienced increased salivation and a peculiar bitter, metallic taste during the first minutes of galanin infusion. The infusion caused no changes in pulse rate or blood pressure. Apart from the taste sensation none of the subjects experienced any discomfort or any other unusual sensations during the infusion.

The infusion resulted in a stable plateau at approximately $1500 \mathrm{pmol} / \mathrm{l}$ (Fig. 1) as compared to a range of basal values between $20-30 \mathrm{pmol} / \mathrm{l}$ maintained both before galanin infusion and throughout the control experiment $(p<0.001)$. At the end of infusion galanin concentrations decreased rapidly. The half-time for the plasma elimination was $3.7 \pm 0.4 \mathrm{~min}$ and the metabolic clearence rate (MCR) $48 \pm 12 \mathrm{ml} \cdot \mathrm{kg}^{-1} \cdot \mathrm{min}^{-1}$. The corresponding apparent distribution space, $V_{d}$, was $256 \pm 60 \mathrm{ml} / \mathrm{kg}$.

Growth hormone concentrations increased markedly during galanin infusion reaching a plateau value eight times the pre-infusion concentrations after $40-\mathrm{min}$ infusion ( $p<0.01$; Fig. 1$)$. In contrast, in the control experiment growth hormone concentrations remained unchanged. During the glucose clamp plasma glucose values stabilized at approximately $13 \mathrm{mmol} / \mathrm{l}$ with no discernible differences between the two experimental days (Fig. 2, upper panel). Glucagon concentrations decreased markedly during the clamp without differences between the two experiments (Fig. 2, lower panel). Both insulin and Cpeptide concentrations in peripheral plasma increased in a biphasic manner in response to the clamp, again with no differences between the galanin infusion and the control experiments (Fig. 3).

\section{Discussion}

It is well established that insulin secretion is regulated by both metabolic, endocrine and neural mechanisms. In addition to classic parasympathetic and sympathetic neurotransmitters, peptidergic transmitters seem to play an important role in secretory control [19]. One such peptide is 
galanin, originally isolated from porcine intestinal extracts, but also found in pancreatic nerve fibres in man and experimental animals $[3,4,20]$. Based on extensive experimentation in dogs and rodents it has been established that in these species galanin acts as an inhibitory sympathetic co-transmitter $[5,20,21]$. However, when investigated in humans it has been impossible to demonstrate any effect of porcine galanin on glucose-stimulated insulin secretion $[9,22]$, although a weak effect was noted in isolated human islets [23]. In isolated perfused pig pancreas porcine galanin was demonstrated to stimulate insulin secretion [10]. The lack of effect of porcine galanin in humans could be due to the differences in amino acid sequence between porcine and human galanin $[1,11]$. The present investigation shows that synthetic human galanin infused at a rate of $74 \mathrm{pmol} \cdot \mathrm{kg}^{-1} \cdot \mathrm{min}^{-1}$ is without effect on insulin secretion in man during the conditions of a hyperglycaemic clamp. This system was chosen because it is generally accepted as being the most sensitive method for revealing inhibitory effects on insulin secretion. The synthetic peptide was not biologically inactive. In humans growth hormone secretion has been demonstrated to be increased by i. v. infusion of porcine galanin [24], and the human peptide had a similar effect. Porcine galanin infused at a dose of $80 \mathrm{pmol} \cdot \mathrm{kg}^{-1} \cdot \mathrm{min}^{-1}$ was reported as causing a very similar, slow increase in growth hormone secretion [9] as the increase we found. It is noteworthy that similar elevations of galanin concentrations in plasma were obtained in the two studies, suggesting that the two peptides were equally potent. It is apparent from our results that glucose metabolism also remained unaffected during the galanin infusion. Thus, identical glucose infusion rates produced identical blood glucose concentrations with and without galanin. In agreement with these results there were no differences in glucagon secretion, which was equally supressed in the two experiments.

Our experiments do not rule out that human galanin may inhibit insulin secretion in man, but merely show that the concentrations obtained in these experiments had no inhibitory effect. Even higher concentrations of galanin might possibly inhibit insulin secretion. On the other hand, in dogs galanin infused at a rate of $25 \mathrm{pmol} \cdot \mathrm{kg}^{-1}$. $\mathrm{min}^{-1}$ inhibited insulin secretion by as much as $70 \%$ [3] and concentrations of $1 \mathrm{nmol} / \mathrm{l}$ caused a $90 \%$ decrease of insulin secretion in isolated perfused dog pancreas [25]. Similarly, in humans lower doses of porcine galanin had profound effects on a number of meal-induced gastrointestinal responses, including gastric emptying, intestinal transit, and insulin concentrations [26], and infusion rates as low as $7.8 \mathrm{pmol} \cdot \mathrm{kg}^{-1} \cdot \mathrm{min}^{-1}$ were found to increase growth hormone secretion [23]. Thus, even if extraordinarily high doses of human galanin were demonstrated as having inhibitory effects on glucose-stimulated insulin secretion in humans, the peptide could still not be considered as very potent. This is in contrast to recent findings in rat insulinoma-derived RIN cells where both human and porcine galanin were reported to be potent inhibitors [27].

Therefore, it seems likely that differences between species can explain the discrepant effects of galanin in humans, rats and dogs. Human beta cells may not have galanin receptors, or, if galanin receptors are present on human beta cells, they may not be able to couple to an inhibitory intracellular machinery. The physiological functions of human galanin are therefore likely to take place in central nervous control of pituitary function and in the enteric nervous system rather than in the pancreas [28].

The half-life of galanin in plasma was $3.7 \pm 0.4 \mathrm{~min}$ and the metabolic clearance rate could be calculated as $48 \pm 12 \mathrm{ml} \cdot \mathrm{kg}^{-1} \cdot \mathrm{min}^{-1}$. These values are comparable to those of other peptide neurotransmitters which are typically eliminated very rapidly from the circulation upon infusion. It is of interest that very similar values were found for porcine galanin in humans [23], indicating that the differences in structure are of minor importance for its elimination kinetics.

Acknowledgements. This work was supported by grants from the Danish Medical Research Council. J.J.H. was supported by the Danish Biotechnology Programme.

\section{References}

1. Tatemoto K, Rökaeus $\AA$, Jörnvall H, McDonald TJ, Mutt V (1983) Galanin - a novel biologically active peptide from porcine intestine. FEBS Lett 164:124-128

2. Rökaeus Å (1987) Galanin: a newly isolated biologically active neuropeptide. Trends Neurosci 10: 158-164

3. Dunning BE, Ahren B, Veith RC, Bötcher G, Sundler F, Taborsky GJ (1986) Galanin: a novel pancreatic neuropeptide. Am J Physiol 251:E127-E133

4. Shimosegawa T, Moriisumi S, Koizumi M, Kashimura J, Yanaihara N, Toyota T (1992) Immunohistochemical demonstration of galanin like immunoreactive nerves in the human pancreas. Gastroenterology 102: 263-271.

5. Dunning BE, Taborsky GJ (1988) Galanin - sympathetic neurotransmittter in endocrine pancreas - ? Diabetes 37: 1157-1162

6. Amiranoff B, Servin AL, Rouyer-Fessard C, Couvineau A, Tatemoto K, Laburthe M (1987) Galanin receptors in a hamster pancreatic $\beta$-cell tumor: identification and molecular characterization. Endocrinology 121: 284-289

7. Homaidan FR, Sharp GWG, Nowak LM (1991) Galanin inhibits a dihydropyridine-sensitive $\mathrm{Ca}^{2+}$ current in the RINm $5 \mathrm{f}$ cell line. Proc Natl Acad Sci USA 88: 8744-8748

8. Lindskog S, Ahrén B (1992) Studies on the mechanism by which galanin inhibits insulin secretion in islets. Eur J Pharmacol 205: 21-27

9. Gilbey SG, Stephenson J, O'Halloran DJ, Burrin JM, Bloom SR (1989) High-dose porcine galanin infusion and effect on intravenous glucose tolerance in humans. Diabetes 38: 1114-1116

10. Messel T, Harling H, Böttcher G, Johnsen AH, Holst JJ (1990) Galanin in the porcine pancreas. Regul Pept 28: 161-176

11. Bersani M, Johnsen AH, Højrup P, Dunning BE, Andreasen JJ, Holst JJ (1991) Human galanin: primary structure and identification of two molecular forms. FEBS Lett 283: 189-194

12. Tam JP, Heath WF, Merrifield RB (1983) $\mathrm{S}_{\mathrm{N}} 2$ deprotection of synthetic peptides with a low concentration of HF in dimethyl sulfide: evidence and application in peptide synthesis. $\mathrm{J}$ Am Chem Soc 105: 6442-6446

13. Ørskov H, Thomsen HE, Yde H (1968) Wick-chromatography for rapid and reliable immunoassay of insulin, glucagon and growth hormone. Nature 219: 193-195

14. Albano JDM, Ekins RP, Maritz G, Turner RC (1972) A sensitive precise radioimmunoassay of serum insulin relying on charcoal separation of bound and free hormone moieties. Acta Endocrinol (Copenh) 70: 487-509

15. Holst JJ (1980) Evidence that glicentin contains the entire sequence of glucagon. Biochem J 187: 337-343 
16. Heding LG (1975) Radioimmunological determination of human C-peptide in serum. Diabetologia 11: 541-548

17. Holst JJ, Bersani M (1991) Assays for the peptide products of somatostatin gene expression. Meth Neurosci 5: 3-21

18. Goldstein A, Aronow L, Kalman SM (1974) Principles of drug action: the basis of pharmacology. Wiley, New York, p 323

19. Holst JJ (1992) Role of classical and peptidergic neurotransmitters in insulin secretion. In: Flatt PR (ed) Nutrient regulation of insulin secretion. Portland Press, London, pp 23-40

20. Ahren B, Böttcher G, Kowalyk S, Dunning BE, Sundler F, Taborsky GJ (1990) Galanin is co-localized with noradrenaline and neuropeptide $\mathrm{Y}$ in dog pancreas and celiac ganglion. Cell Tiss Res 261: 49-58

21. Dunning BE, Taborsky GJ (1989) Galanin release during pancreatic nerve stimulation is sufficient to influence islet function. Am J Physiol 256:E191-E198

22. Ahren B (1990) Effects of galanin and calcitonin gene-related peptide on insulin and glucagon secretion in man. Acta Endocrinol (Copenh) 123: 591-597

23. Ahren B, Ar'Rajab A, Böttcher G, Sundler F, Dunning BE (1991) Presence of galanin in human pancreatic nerves and inhibition of insulin secretion from isolated human islets. Cell Tiss Res 164: 263-267

24. Bauer FE, Venetikou M, Burrin JM, Ginsberg L, MacKay DJ, Bloom SR (1986) Growth hormone release in man induced by galanin, a new hypothalamic peptide. Lancet II: 192-194
25. Hermansen K (1988) Effects of galanin on the release of insulin, glucagon and somatostatin from the isolated, perfused dog pancreas. Acta Endocrinol (Copenh) 119: 91-98

26. Bauer FE, Zintel A, Kenny MJ, Calder D, Ghatei MA, Bloom SR (1989) Inhibitory effect of galanin on postprandial gastrointestinal motility and gut hormone release in humans. Gastroenterology 97: 260-264

27. McKnight GL, Karlsen AE, Kowalyk S, et al (1992) Sequence of human galanin and its inhibition of glucose-stimulated insulin secretion from RIN cells. Diabetes 41:82-87

28. Rattan S (1991) Role of galanin in the gut. Gastroenterology 100: 1762-1768

Received: 11 January 1993

and in revised form: 10 March 1993

Dr. J.J.Holst

Department of Medical Physiology

The Panum Institute

Blegdamsvej 3

DK-2200 Copenhagen $N$

Denmark 